\title{
FACILITATING THE ADULT LEARNING PROCESSES IN SECOND CHANCE EDUCATION: WHAT DO THE LATVIAN ADULT LEARNERS AND THEIR EDUCATORS THINK ABOUT?
}

\author{
Svetlana Surikova \\ University of Latvia
}

\begin{abstract}
The paper aims at presenting the findings of the research on core competences of adult educators conducted in Latvia during the study "Identification and analysis of new challenges and solutions that have influence on engagement and reintegration of adults (1824 years) in lifelong learning" funded by ESF project "Support to research in educational field" (sub-activity 1.2.2.3.2.), No 011/0011/1DP/1.2.2.3.2/11/IPIA/VIAA/001. The adult educators and adult learners from the field of second chance education (evening shift schools) were involved in an online survey (2011-2012) using the research tool developed in the project "Qualified to Teach" - QF2TEACH. The main research results are analysed in order to identify the core competences of educators as adult learning facilitators and to compare the adult learners and their educators' opinion concerning these competences within the domains: interpersonal behaviour and communication with learners, access and progression of learners, monitoring and assessment of learning processes.
\end{abstract}

Keywords: Adult educator, adult education, adult learner, adult learning, andragogy, learning processes, second chance education.

\section{Introduction}

In Latvia, "adult education is seen [...] as a diverse process offering personal development and the capacity to cope in the labour market throughout life" (EAEA, 2011, p. 4). Furthermore, as it is mentioned in EAEA (2011) report, "the main goal of adult learning in Latvia is to provide individuals with the opportunity to obtain or complement existing learning based on needs and interests, irrespective of age, sex and previous education with an emphasis on up-skilling or re-skilling” (p. 5). However according to Deggs \& Miller (2011), "the role of the adult educator can become more uncertain when attempting to address individual needs that are fundamentally representative of the complex issues within communities" (p. 25).

It should be specified that for the purpose of this paper the understanding of notion adult proposed by Jarvis (2012) will be provided: according to him, "the term adult refers to a social status rather than a biological age, since in some countries in the world adulthood is achieved at younger biological ages than in others. This point does demonstrate the significance of recognising that learning does not occur in social isolation and that the occurrence of different forms of learning may be the result of social and cultural pressures rather than biological differences alone" (p. 11). According to Booth and Schwartz's (2012) study, "prior to the 1970s, information about adults as learners was based on psychological perspectives about learning in general (...); however, with the 
publications of several key texts, the most notable being Malcolm Knowles's The Adult Learner: A Neglected Species (1973), theorists and practitioners began to focus on attempting to understand the unique learning processes and characteristics of adults as learners" (p. 43). In 1973, Knowles noted that "andragogical theory is based on at least four main assumptions that are different from those of pedagogy: (a) changes in self-concept, (b) the role of experience, (c) readiness to learn, and (d) orientation to learning" (pp. 45-47). More recently, Knowles, Holton and Swanson (2011) discussed new perspectives on andragogy emerged from research and theory in different disciplines taking into the consideration the "core andragogical principles" such as "the learner's need to know, self-directed learning, prior experiences of the learner, readiness to learn, orientation to learning and problem solving, and motivation to learn" (p. 181). Furthermore, Knowles, Holton and Swanson (2011) described eight elements of the andragogical process such as "preparing the learners, considering the physical and psychological climate setting, involving the learners in planning for their learning, involving the learners in diagnosing their own needs for learning, involving the learners in formulating their own learning objectives, involving the learners in designing learning plans, helping the learners carry out their learning plans, and involving the learners in evaluating their own learning outcomes" (p. 300).

In many recent studies (Deggs \& Miller, 2011; Keogh, 2009; Knowles, Holton \& Swanson, 2011; Nuissl \& Egetenmeyer, 2010; Nuissl \& Lattke, 2008; Research voor Beleid, 2008, 2010, etc) it is argued that the quality of adult educators has an influence on the quality of adult learning. It is important to think about the future of adult education and learning from the perspective of adult educators and adult learners. This idea was recently explored by Schmidt (2013). He indicated that "the future means being flexible, using technology wisely, partnering and working together, promoting and sharing the achievements and successes, focusing on professional sustainability" (Schmidt, 2013:79-80).

In Latvia, "the main challenge in the present day situation of adult education is how to increase the participation rate in adult learning", therefore the "enhancement of the second chance education opportunities, especially for socially at risk groups" is recognised as a priority in adult education policy (EAEA, 2011:5). The purpose of this paper is to present the key empirical findings of the research on core competences of adult educators from the field of second chance education conducted in Latvian evening shift schools in 20112012 using QF2TEACH (www.qf2teach.eu) first wave questionnaire. The main research results will be analysed in order to identify the core competences of adult educators and to compare the adult learners and their educators' opinion concerning these competences within the domains such as interpersonal behaviour and communication with learners, access and progression of learners, monitoring and assessment of learning processes. 


\section{Context and Sample of the Research}

The QF2TEACH first wave questionnaire (Bernhardsson \& Lattke, 2011:66-81) on the core competences of learning facilitators in adult and continuing education was used in the frame of the collaborative study "Identification and analysis of new challenges and solutions that have influence on engagement and reintegration of adults (18-24 years) in lifelong learning" funded by ESF project "Support to research in educational field" (sub-activity 1.2.2.3.2.), No 011/0011/1DP/1.2.2.3.2/11/IPIA/VIAA/001. The original questionnaire was translated into Latvian and Russian and created as a web-based survey tool (i.e. online questionnaire) using Google forms. The translated questionnaires were sent to 6 voluntary experts to provide feedback on it's adaptation to Latvian context. In October 2011 the email invitation of participating in the web-based survey was sent out to 507 potential respondents (155 adult educators and 352 adult learners) from the field of second chance education (20 evening shift schools). In February 2012 online survey yielded a total of 118 respondents (64 adult educators and 54 adult learners) for a response rate of $23 \%$ (see Table 1).

\section{Latvian respondents' gender and age}

Table 1

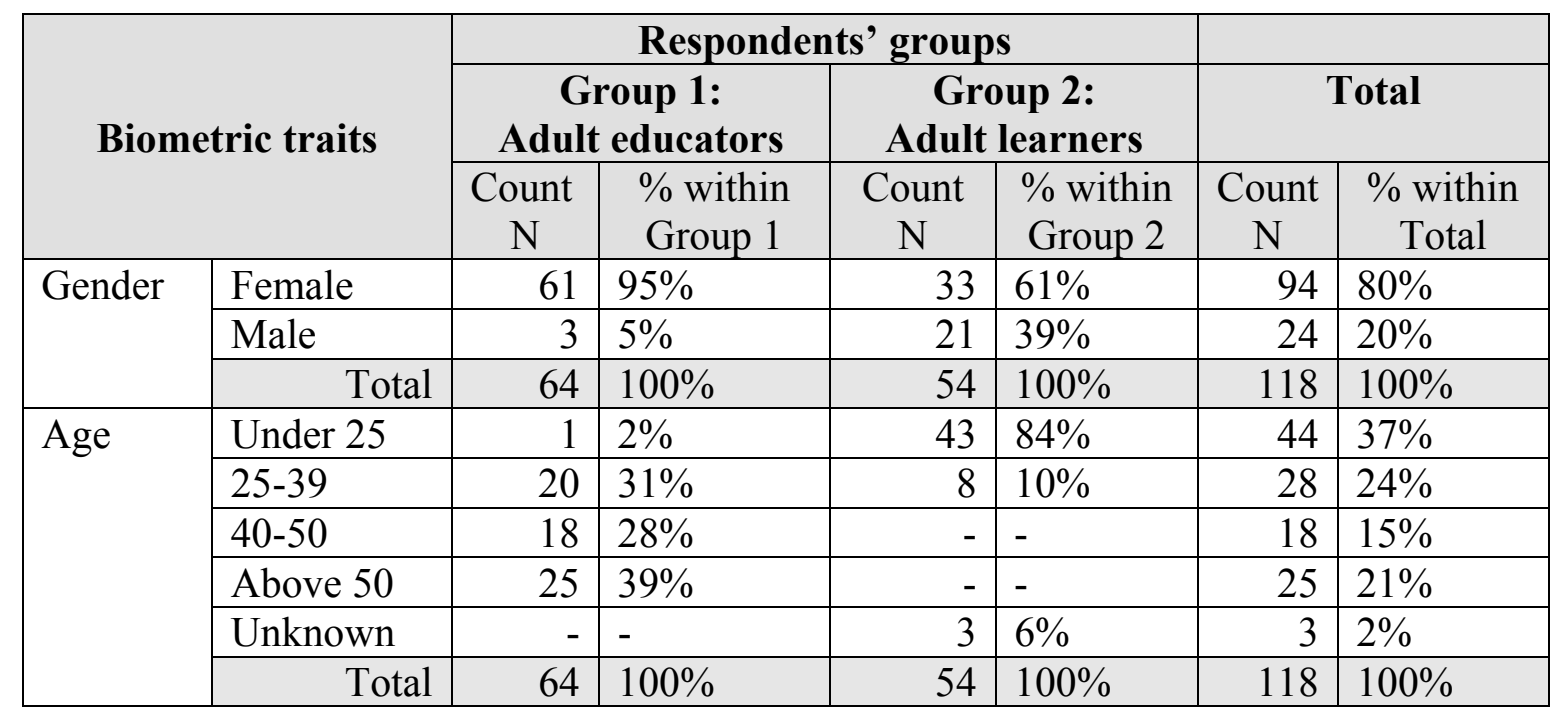

\section{Empirical Findings of the Research: Comparative Analysis}

The obtained quantitative data were processed and analysed using SPSS 17.0 software. Mann-Whitney U test was run to determine if there were statistically significant differences in respondents' view regarding the competences of educators as adult learning facilitators within the domains such as interpersonal behaviour and communication with learners, access and progression of learners, monitoring and assessment of learning processes between adult learners and their educators from the field of second chance education (evening shift schools) in Latvia. Firstly, within each domain the respondents were asked to indicate 
how important are certain skills or behaviour currently. For each item a rating had to be given on a 6-point Likert scale from 'irrelevant' (score 1) up to 'indispensable' (score 6). Secondly, the respondents were asked for the future importance of the same skills or behaviour indicating if the respective item would be 'less important' (score 1), 'equally important' (score 2) or 'more important' (score 3) in 2015. Finally, each domain ended with open-minded questions asking the additional comments.

\section{Domain 1: Interpersonal behaviour and communication with learners}

From the current perspective, all the items mentioned in Table 2 (except the item "to use suitable body language") were rated higher by the adult educators in comparison with the adult learners. The further analysis reveals that there is a statistically significant difference in the mean rank scores obtained on the item "to communicate clearly" ( $p=.022)$ and item "to handle conflicts" $(p=.018)$ between adult learners and their educators' point of view (see Table 2).

Table 2

Interpersonal behaviour and communication with learners: Current perspective

\begin{tabular}{|c|c|c|c|c|}
\hline \multirow{3}{*}{ Items } & \multicolumn{4}{|c|}{ Mann-Whitney U test } \\
\hline & \multicolumn{2}{|c|}{ Mean rank } & \multirow[b]{2}{*}{ U-value } & \multirow[b]{2}{*}{$\begin{array}{c}\text { Asymp. } \\
\text { Sig. }\end{array}$} \\
\hline & $\begin{array}{c}\text { Adult } \\
\text { educators }\end{array}$ & $\begin{array}{c}\text { Adult } \\
\text { learners }\end{array}$ & & \\
\hline To motivate & 63.95 & 54.22 & 1443.00 & .064 \\
\hline To inspire & 63.17 & 55.15 & 1493.00 & .148 \\
\hline To use suitable body language & 59.05 & 60.03 & 1699.50 & .872 \\
\hline To communicate clearly & 64.97 & 53.02 & 1378.00 & .022 \\
\hline To manage group dynamics & 63.16 & 55.17 & 1494.00 & .171 \\
\hline To handle conflicts & 65.52 & 52.37 & 1343.00 & .018 \\
\hline $\begin{array}{l}\text { To act considering democratic } \\
\text { values }\end{array}$ & 63.34 & 54.94 & 1482.00 & .147 \\
\hline
\end{tabular}

From the future perspective (see Table 3), the items such as "to inspire", "to use suitable body language" and "to communicate clearly" were rated higher by the adult learners when compared with the adult educators. As it is shown in Table 3 , there is no statistically significant difference in rating of all the items between adult learners and their educators' opinion. However the majority of adult educators (from $46.9 \%$ up to $64.1 \%$ ) evaluated the future importance of all the competences (except the item "to use suitable body language") as "more important' in the future. In adult learners' opinion (from 55.6\% up to $63.0 \%$ ), the competences such as "to inspire", "to communicate clearly" and "to handle conflicts" will be more important in the future. 
Interpersonal behaviour and communication with learners: Future perspective

\begin{tabular}{|c|c|c|c|c|}
\hline \multirow{3}{*}{ Items } & \multicolumn{4}{|c|}{ Mann-Whitney U test } \\
\hline & \multicolumn{2}{|c|}{ Mean rank } & \multirow[b]{2}{*}{ U-value } & \multirow[b]{2}{*}{$\begin{array}{c}\text { Asymp. } \\
\text { Sig. }\end{array}$} \\
\hline & $\begin{array}{c}\text { Adult } \\
\text { educators }\end{array}$ & $\begin{array}{c}\text { Adult } \\
\text { learners }\end{array}$ & & \\
\hline To motivate & 61.12 & 57.58 & 1624.50 & .513 \\
\hline To inspire & 59.23 & 59.82 & 1710.50 & .912 \\
\hline To use suitable body language & 58.91 & 60.20 & 1690.00 & .821 \\
\hline To communicate clearly & 58.87 & 60.25 & 1687.50 & .797 \\
\hline To manage group dynamics & 59.72 & 59.24 & 1714.00 & .932 \\
\hline To handle conflicts & 60.97 & 57.76 & 1634,00 & .556 \\
\hline To act considering democratic values & 59.76 & 59.19 & 1711.50 & .921 \\
\hline
\end{tabular}

\section{Domain 2: Access and progression of learners}

From the current perspective, all the items mentioned in Table 4 (except the item "to provide information about further training opportunities in relation to own specialist area") were rated higher by the adult educators in comparison with the adult learners. The further analysis reveals that there is a statistically significant difference in the mean rank scores obtained on the item "to refer learners to information on current and future learning opportunities" $(p=.026)$, item "to encourage learners to take over responsibility for their future learning processes" $(p=.024)$ and item "to assess the entry-level of learners" $(p=.045)$ between adult learners and their educators' point of view (see Table 4).

Table 4

Access and progression of learners: Current perspective

\begin{tabular}{|c|c|c|c|c|}
\hline \multirow{3}{*}{ Items } & \multicolumn{4}{|c|}{ Mann-Whitney U test } \\
\hline & \multicolumn{2}{|c|}{ Mean rank } & \multirow{2}{*}{$\begin{array}{c}\mathrm{U}- \\
\text { value }\end{array}$} & \multirow[b]{2}{*}{$\begin{array}{l}\text { Asymp. } \\
\text { Sig. }\end{array}$} \\
\hline & $\begin{array}{c}\text { Adult } \\
\text { educators }\end{array}$ & $\begin{array}{c}\text { Adult } \\
\text { learners }\end{array}$ & & \\
\hline $\begin{array}{l}\text { To refer learners to information on current and } \\
\text { future learning opportunities }\end{array}$ & 65.23 & 52.70 & 1361.00 & .026 \\
\hline $\begin{array}{l}\text { To provide information about further training } \\
\text { opportunities in relation to own specialist area }\end{array}$ & 58.25 & 60.98 & 1648.00 & .636 \\
\hline $\begin{array}{l}\text { To refer learners to information about } \\
\text { different external support structures (e.g., } \\
\text { grants, childcare) }\end{array}$ & 60.20 & 58.67 & 1683.00 & .795 \\
\hline $\begin{array}{l}\text { To analyse typical barriers that may be faced } \\
\text { by adults returning to learning }\end{array}$ & 60.66 & 58.12 & 1653.50 & .666 \\
\hline $\begin{array}{l}\text { To encourage learners to take over } \\
\text { responsibility for their future learning } \\
\text { processes }\end{array}$ & 65.30 & 52.63 & 1357.00 & .024 \\
\hline To assess the entry-level of learners & 64.52 & 53.55 & 1406.50 & .045 \\
\hline
\end{tabular}


From the future perspective, all the items mentioned in Table 5 (except the item "to encourage learners to take over responsibility for their future learning processes") were rated higher by the adult learners when compared with the adult educators. As it is shown in Table 5, there is no statistically significant difference in rating of all the items between adult learners and their educators' opinion. However, from the point of view of the majority of adult learners (from $48.1 \%$ up to $53.7 \%$ ), the competences such as "to provide information about further training opportunities in relation to own specialist area", "to refer learners to information about different external support structures (e.g., grants, childcare)" and "to assess the entry-level of learners" will be more important in the future. The majority of adult educators (54.7\%) evaluated the future importance of competence "to encourage learners to take over responsibility for their future learning processes" as 'more important' in the future.

Access and progression of learners: Future perspective

Table 5

\begin{tabular}{|c|c|c|c|c|}
\hline \multirow{3}{*}{ Items } & \multicolumn{4}{|c|}{ Mann-Whitney U test } \\
\hline & \multicolumn{2}{|c|}{ Mean rank } & \multirow[b]{2}{*}{ U-value } & \multirow[b]{2}{*}{$\begin{array}{c}\text { Asymp. } \\
\text { Sig. }\end{array}$} \\
\hline & $\begin{array}{c}\text { Adult } \\
\text { educators }\end{array}$ & $\begin{array}{c}\text { Adult } \\
\text { learners }\end{array}$ & & \\
\hline $\begin{array}{l}\text { To refer learners to information on } \\
\text { current and future learning opportunities }\end{array}$ & 58.57 & 60.60 & 1668.50 & .714 \\
\hline $\begin{array}{l}\text { To provide information about further } \\
\text { training opportunities in relation to own } \\
\text { specialist area }\end{array}$ & 57.04 & 62.42 & 1570.50 & .334 \\
\hline $\begin{array}{l}\text { To refer learners to information about } \\
\text { different external support structures (e.g., } \\
\text { grants, childcare) }\end{array}$ & 58.54 & 60.64 & 1666.50 & .705 \\
\hline $\begin{array}{l}\text { To analyse typical barriers that may be } \\
\text { faced by adults returning to learning }\end{array}$ & 57.30 & 62.11 & 1587.00 & .383 \\
\hline $\begin{array}{l}\text { To encourage learners to take over } \\
\text { responsibility for their future learning } \\
\text { processes }\end{array}$ & 62.73 & 55.67 & 1521.00 & .204 \\
\hline To assess the entry-level of learners & 58.59 & 60.57 & 1670.00 & .720 \\
\hline
\end{tabular}

\section{Domain 3: Monitoring and assessment of learning processes}

From the current perspective, all the items mentioned in Table 6 were rated higher by the adult educators in comparison with the adult learners. The further analysis reveals that there is a statistically significant difference in the mean rank scores obtained on all the items (except the item "to assess the needs of the learner") between adult learners and their educators' point of view (see Table 6). From the future perspective, all the items mentioned in Table 7 (except the item "to diagnose the learning attitude of the learner") were rated higher by the adult educators when compared with the adult learners. As it is shown in Table 7, 
there is no statistically significant difference in rating of all the items between adult learners and their educators' opinion.

Monitoring and assessment of learning processes: Current perspective

\begin{tabular}{|c|c|c|c|c|}
\hline \multirow{3}{*}{ Items } & \multicolumn{4}{|c|}{ Mann-Whitney U test } \\
\hline & \multicolumn{2}{|c|}{ Mean rank } & \multirow[b]{2}{*}{ U-value } & \multirow{2}{*}{$\begin{array}{c}\text { Asymp. } \\
\text { Sig. }\end{array}$} \\
\hline & $\begin{array}{c}\text { Adult } \\
\text { educators }\end{array}$ & $\begin{array}{c}\text { Adult } \\
\text { learners }\end{array}$ & & \\
\hline To assess the needs of the learner & 63.91 & 54.28 & 1446.00 & .080 \\
\hline To analyse learning barriers of the learner & 67.14 & 50.44 & 1239.00 & .004 \\
\hline To monitor the learning process & 66.63 & 51.06 & 1272.00 & .005 \\
\hline To evaluate the learning outcomes & 65.70 & 52.15 & 1331.00 & .012 \\
\hline $\begin{array}{l}\text { To diagnose the learning capacity of the } \\
\text { learner }\end{array}$ & 68.33 & 49.04 & 1163.00 & .001 \\
\hline $\begin{array}{l}\text { To diagnose the learning attitude of the } \\
\text { learner }\end{array}$ & 65.21 & 52.73 & 1362.50 & .031 \\
\hline
\end{tabular}

Table 7

Monitoring and assessment of learning processes: Future perspective

\begin{tabular}{|l|l|l|l|l|}
\hline \multirow{2}{*}{\multicolumn{1}{|c|}{ Items }} & \multicolumn{3}{c|}{ Mann-Whitney U test } \\
\cline { 2 - 5 } & \multicolumn{2}{c|}{ Mean rank } & \multicolumn{1}{c|}{$\begin{array}{c}\text { U- } \\
\text { value }\end{array}$} & $\begin{array}{c}\text { Asymp. } \\
\text { Sig. }\end{array}$ \\
\cline { 2 - 5 } & \multicolumn{1}{|c|}{$\begin{array}{c}\text { Adult } \\
\text { educators }\end{array}$} & $\begin{array}{c}\text { Adult } \\
\text { learners }\end{array}$ & & \\
\hline To assess the needs of the learner & 60.16 & 58.71 & 1685.50 & .792 \\
\hline To analyse learning barriers of the learner & 59.60 & 59.38 & 1721.50 & .968 \\
\hline To monitor the learning process & 59.78 & 59.17 & 1710.00 & .911 \\
\hline To evaluate the learning outcomes & 60.86 & 57.89 & 1641.00 & .590 \\
\hline $\begin{array}{l}\text { To diagnose the learning capacity of the } \\
\text { learner }\end{array}$ & 61.70 & 56.89 & 1587.00 & .385 \\
\hline $\begin{array}{l}\text { To diagnose the learning attitude of the } \\
\text { learner }\end{array}$ & 58.84 & 60.28 & 1686.00 & .797 \\
\hline
\end{tabular}

Both the adult educators (51.6\%) and adult learners (50.0\%) evaluated the future importance of competence "to assess the needs of the learner" as "more important' in the future. Furthermore, the adult learners (50.0\%) thought that the competences such as "to analyse learning barriers of the learner" and "to diagnose the learning attitude of the learner" would be more important in the future. On the other hand, the adult educators (53.1\%) thought that the competence "to evaluate the learning outcomes" would be more important in the future. 


\section{Conclusions}

The main research results have been analysed in order to identify the core competences of educators as adult learning facilitators and to compare the adult learners and their educators' opinion concerning these competences within the domains such as interpersonal behaviour and communication with learners, access and progression of learners, monitoring and assessment of learning processes.

As it has been identified, from the current perspective the competences within the domain "Interpersonal behaviour and communication with learners" such as motivating and inspiring the learners, communicating clearly, managing group dynamics, handling the conflicts, and acting taking into consideration democratic values have been rated higher by the adult educators. The adult learners have rated higher on using suitable body language. Furthermore, the majority of adult educators have evaluated the future importance of all the competences (except using suitable body language) as 'more important' in the future. But adult learners thought that inspiring the learners, communicating clearly and handling the conflicts will be more important in the future.

As regards the competences within the domain "Access and progression of learners", it can be summarised that from the current perspective referring the learners to information on current and future learning opportunities, different external support structures (e.g., grants, childcare); analysing the typical barriers that may be faced by adults returning to learning; encouraging the learners to take over responsibility for their future learning processes; assessing the entrylevel of learners have been rated higher by the adult educators. The adult learners have rated higher on providing information about further training opportunities in relation to own specialist area. According to the majority of adult learners, providing information about further training opportunities, referring the learners to information about different external support structures and assessing the entry-level of learners will be more important in the future. The majority of adult educators have evaluated the future importance of encouraging the learners to take over responsibility for their future learning processes as 'more important' in the future.

It can be concluded that from the current perspective all the competences within the domain "Monitoring and assessment of learning processes" (e.g., assessing the needs of the learner, analysing the learning barriers of the learner, monitoring the learning process, evaluating the learning outcomes, diagnosing the learning capacity and learning attitude of the learner) have been rated higher by the adult educators in comparison with adult learners. Both the adult educators and adult learners have evaluated the future importance of assessing the needs of the learner as 'more important' in the future. Furthermore, the adult learners have emphasised that analysing the learning barriers of the learner and diagnosing the learning attitude of the learner would be more important in the 
future as well. On the other hand, the adult educators thought that evaluating the learning outcomes would be more important in the future.

Finally, it should be stressed that encouraging the adult learners to take over responsibility for their learning processes and involving the adult learners in facilitating their own learning processes (e.g., self-motivating, self-inspiring, diagnosing and assessing their own learning needs, monitoring their own learning processes, analysing their own learning barriers, evaluating their own learning outcomes, etc) is a crucial moment not only in the field of second chance education but also in Latvian adult education system as whole.

\section{Bibliography}

1. Bernhardsson, N., \& Lattke, S. (2011). Core competencies of adult learning facilitators in Europe. Findings from a transnational Delphi survey conducted by the project "Qualified to Teach”. Retrieved from http://www.qf2teach.eu/assets/files/ Transnational\%20Report.pdf

2. Booth, M., \& Schwartz, H. L. (2012). We're all adults here: Clarifying and maintaining boundaries with adult learners. New Directions for Teaching \& Learning, 131, 43-55. doi:10.1002/tl.20026

3. Deggs, D., \& Miller, M. (2011). Developing community expectations: The critical role of adult educators. Adult Learning, 22(3), 25-30.

4. EAEA. (2011). Country report on adult education in Latvia. Retrieved from http://www.eaea.org/doc/pub/Country-Report-on-Adult-Education-in-Latvia.pdf

5. Jarvis, P. (2012). Adult learning in the social context. London: Routledge.

6. Keogh, H. (Ed.). (2009). The state and development of adult learning and education in Europe, North America and Israel: Regional synthesis report. Hamburg, Germany: UNESCO Institute for Lifelong Learning. Retrieved from http://www.unesco.org/ fileadmin/MULTIMEDIA/INSTITUTES/UIL/confintea/pdf/GRALE/confinteavi_grale paneurope_synthesis_en.pdf

7. Knowles, M. S. (1973). The adult learner: A neglected species. Houston, TX: Gulf Publishing. Retrieved from http://files.eric.ed.gov/fulltext/ED084368.pdf

8. Knowles, M. S., Holton, E. F., \& Swanson, R. A. (2011). The adult learner: The definitive classic in adult education and human resource development. Oxford: Elsevier Inc. doi:10.1016/B978-1-85617-811-2.00001-8

9. Nuissl, E., \& Lattke, S. (Eds.). (2008). Qualifying adult learning professionals in Europe. Bielefeld: W. Bertelsmann Verlag.

10. Nuissl, E., \& Egetenmeyer, R. (Eds.). (2010). Teachers and trainers in adult and lifelong learning: Asian and European perspectives. Frankfurt am Main: Peter Lang.

11. Research voor Beleid. (2008). ALPINE - Adult Learning Professions in Europe. A study of the current situation, trends and issues. Final report. Retrieved from http://ec.europa.eu/education/more-information/doc/adultprofreport_en.pdf

12. Research voor Beleid. (2010). Key competences for adult learn.ing professionals. Contribution to the development of a reference framework of key competences for adult learning professionals. Final report. Retrieved from http://ec.europa.eu/education/ more-information/doc/2010/keycomp.pdf 
Proceeding of the International Scientifical Conference May $23^{\text {th }}-24^{\text {th }}, 2014$ Volume II

13. Schmidt, S. W. (2013). The future of adult education. Adult Learning, 24(2), 79-81. doi:10.1177/1045159513477849

Dr.paed.

Svetlana Surikova
Pedagogical Sciences of the Faculty of Education, Psychology and Art of the University of Latvia

Email:Svetlana.surikova@lu.lv

Phone: + 37126899707 